
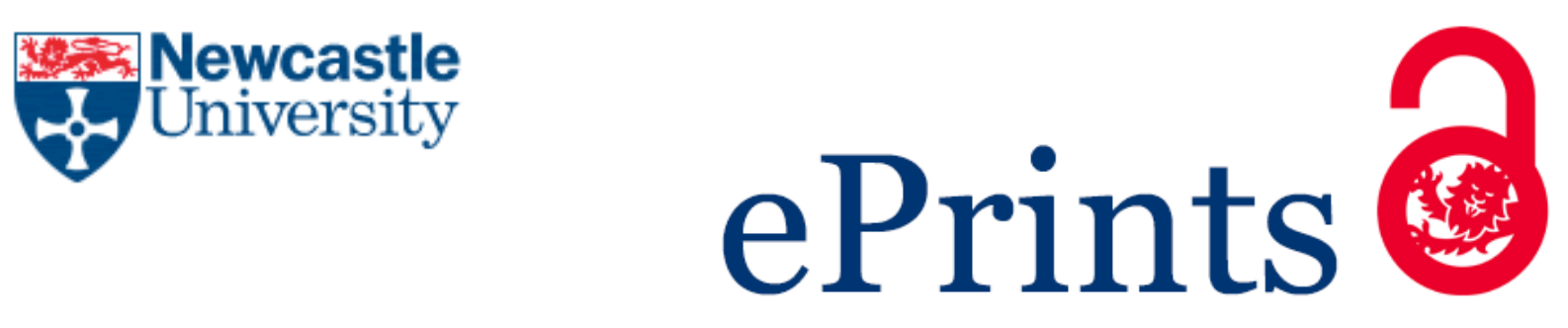

\title{
Coward M.
}

Hot Spots/Cold Spots: Infrastructural Politics in the Urban Age. International Political Sociology 2015, 9(1), 96-99.

\section{Copyright:}

This is the peer reviewed version of the following article, which has been published in final form at http://dx.doi.org/10.1111/ips.12081. This article may be used for non-commercial purposes in accordance with Wiley Terms and Conditions for Self-Archiving.

Date deposited:

$17 / 10 / 2014$

Embargo release date:

11 March 2017 
Hot Spots/Cold Spots: Infrastructural Politics in the Urban Age

\section{Martin Coward Newcastle University, UK}

Tracing the political stakes of contemporary global urbanisation requires a shift in focus from cities to infrastructure. Focusing on the dynamics of infrastructural urbanism gives a clearer understanding of the ontology and politics of the global urban than analyses focused on the city (e.g., Magnusson, 2011). This reorientation reveals a political dynamic of (dis)connection at the heart of global urbanisation. This dynamic is exemplified by the hot and cold spots of global urbanisation where infrastructural connectivity is at stake.

Brenner and Schmid $(2013,744)$ note that current understandings of the 'urban age' conceptualise 'urbanization primarily or exclusively with reference to the concentration of population within cities or urban settlements'. This is perhaps best exemplified by those who see the politics of the global urban in terms of the relocation of the locus of political authority from the state to the city (e.g., Sassen, 2010). Such accounts of the politics of the urban age are often focused on the growth of centres of population density and the questions of governance raised by the attendant intensification of flows of money, people and goods. However, infrastructures de-centre the city, leading to polycentric urban agglomerations. A focus on infrastructures thus leads us to think about the urban beyond the constraints of the city.

Infrastructure is 'the connective tissue that knits people, places, social institutions and the natural environment into coherent urban relations' (Graham and Marvin, 2001, 43). Infrastructure articulates heterogeneous subjects and spaces together, creating polycentric, plural agglomerations often imagined as grid-like networks composed of lines of transmission intersecting at nodes of urban density. Insofar as it generates urban agglomerations, infrastructure erodes the usefulness of the city as a distinct place or concept. Indeed, the infrastructures of the 'infinite city' (Skeates, 1997) stretch into the hinterlands of urban agglomeration. This erosion of the city as an analytic category marks out contemporary infrastructural urbanism from previous, historical iterations. Where previous iterations of infrastructure were oriented towards the unitary project of the city (often in the form of public works), contemporary infrastructure is characterised by global reach, extending beyond the city as both place and idea(I). As such, the political implications of global urbanisation are best read not in terms of a city centric framework, but in terms of an infrastructural urbanism on a global scale.

To see such infrastructural urbanism in action consider Chinese plans to 'create a 16,000 sq mile urban area...stretching from Guangzhou to Shenzhen' adjacent to Macau and Hong Kong (Moore \& Foster, 2011). The result will be a metropolitan region of $42-50$ million inhabitants (Chang, 2011). At the heart of this project are 150 infrastructure projects scheduled to cost $£ 190$ Billion (Moore \& Foster, 2011). This project embodies the dynamics of infrastructural urbanism in which previously distinct city centres are linked producing polycentric urban agglomerations. Infrastructure is central to this dynamic: rails, roads, concrete, wires, and pipes constitute the links that connect multiple city-centres into an urban region.

Ontologically, infrastructural urbanism is perceived to be characterised by connectivity. This perceived ontology of connection is highlighted by the securitisation of infrastructure - its elevation to the status of critical resource. The discursive problematisation of infrastructure as an object of security reveals a distinctive imagination of the vulnerability of life in the global urban era (Collier \& Lakoff, 2008): a 
vulnerability to cascading failure that could expose urban life to catastrophic disconnection (Graham, 2010). Securitisation of infrastructure is oriented towards preventing, pre-empting, or recovering from, disconnection. The securitisation of global infrastructural urbanism has been accompanied by a reciprocal dynamic of organised violence (Coward, 2009) as militant organisations seek to exploit the vulnerability of urban societies to disconnection. Pipes, wires, roads and rails have thus become hot spots, the focal point for both the deployment of armed forces to protect infrastructures and disruptive attacks by militant organisations. As such, the securitisation of infrastructure as the key vulnerability of the global urban era is mutually constituted by an attendant violent contestation of that infrastructure.

This contestation of infrastructure throws into relief the locus of the political in an era of global urbanisation. The interpretation of global urbanisation as predicated on the connectivity established by infrastructure is an 'ontopolitics': a particular 'interpretation...[of] the possible relations humans can establish' (Connolly, 1995, p.1). The ontopolitical imaginary of infrastructural urbanism is one in which life is defined by connectivity. The loss of connectivity (or a threat of such loss) is thus seen as a threat to life itself. This ontopolitics is thus constitutive of a political dynamic of inclusion and exclusion: connection and disconnection. Here I take politics to be located in the constitution of relations. Connection and disconnection are modes of relation. Politics is thus less disagreement in Ranciere's terms (1999), and more a contest over the manner in which relations can be formed or dissolved. It is less a question of who counts, than a question of who connects (or perhaps a question of being counted because you are connected). Put differently, the securitisation and violent contestation of infrastructure in response to its perceived connective powers constitutes a struggle over inclusion and exclusion. At the hotspots of critical infrastructure the drama of who is to be connected is played out in an explicit fashion.

However, while the hot spots of infrastructural urbanism take the headlines, there is an equally violent politics of global urbanisation played out in infrastructural 'cold spots' (Moss 2008). Broadly speaking we might identify these cold spots as places where the connectivity of infrastructure is lacking. There are two interlinked patterns of infrastructure in such cold spots. On the one hand these infrastructures might be informal, incomplete, dysfunctional or abandoned. On the other while functional infrastructures might cross or border these cold spots, they may be unavailable and inaccessible (for reasons of either securitisation, privatisation or pricing). Such cold spots are often correspondingly characterised in discourses of global urbanisation as incomplete, informal or dysfunctional forms of urbanism. This dynamic is revealed in the struggle over sanitation infrastructures in the global south. As McFarlane $(2012,1287)$ notes, '[e]very hour, 42 children across India die due to inadequate sanitation...yet the central Indian state spends only $0.2 \%$ of GDP on sanitation and drinking water'. At stake in this 'malevolent urbanism' (McFarlane, 2012) is the disconnection effected by a lack of functional infrastructure. And while improvised infrastructures arise, they are faint approximations of the connectivity enjoyed in so-called global cities.

The ontopolitics of infrastructural urbanism are thus expressed in the struggle for connectivity that takes place in the hot and cold spots of global urbanisation. A focus on the contestation of, and struggles for, connectivity are a key heuristic for disclosing the political stakes of or the urban age. Disconnection, denial of access, or failure of full provision are political moments in which subjects are excluded from what is commonly perceived to constitute full enjoyment of the global urban way of life. Similarly providing and controlling connectivity constitutes a considerable power: a power to shape and form relations. Thus the question of the politics of the global urban demands a turn to the various attacks on, securitisations of, or struggles to achieve, connection embodied in the infrastructure hot/cold spots of global urbanisation. The politics of the global urban will not, therefore, be revealed by shifting analyses 
of governance from the state to the city. Rather it requires a tracing out of the various empirical struggles over the infrastructures of global urbanisation from securitised cityscapes through violent attacks on the conduits of the global economy to the various demands for a right to be connected (to sanitation, the internet and so on). In such tracings of connectivity we will be able to discern the political stakes of global urbanisation: inclusion and exclusion through connection and disconnection.

\section{$\underline{\text { References }}$}

Brenner, Neil and Schmid, Christian (2014) 'The 'Urban Age' in Question', International Journal of Urban and Regional Research, 38(3), pp.731-55

Chang, Gordon C (2011). 'A City of 260 Million. Where Else But China?', Forbes [online], Available from: http://www.forbes.com/sites/megacities/2011/04/11/a-city-of-260-million-where-else-but-china/ [Accessed 30 August 2014]

Collier, Stephen J \& Lakoff, Andrew (2008) 'The Vulnerability of vital systems: how 'critical infrastructure' became a security problem', in Dunn Cavelty, Myriam and Kristensen, Kristian, eds., Securing 'the homeland'; Critical infrastructure, risk and (in)security, London: Routledge, pp. 17-39.

Connolly, William (1995) The Ethos of Pluralization. Minneapolis: University of Minnesota Press

Coward, Martin (2009) 'Network-Centric Violence, Critical Infrastructure and the Urbanization of Security', Security Dialogue, 40, pp.399-418

Graham, Stephen (2010) Disrupted Cities: When Infrastructure Fails. New York: Routledge.

Graham, Stephen \& Marvin, Simon (2001) Splintering Urbanism: Networked Infrastructures, Technological Mobilities and the Urban Condition. Routledge, London

Magnusson, Warren (2011) Politics of Urbanism: Seeing Like a City. London: Routledge.

McFarlane, Colin (2012) 'From sanitation inequality to malevolent urbanism: The normalisation of suffering in Mumbai', Geoforum 43, pp.1287-1290

Moore, Malcolm \& Foster, Peter (2011), 'China to create largest mega city in the world with 42 million people', The Telegraph [online], 24 January, Avalible from: http://www.telegraph.co.uk/news/worldnews/asia/china/8278315/China-to-create-largest-mega-cityin-the-world-with-42-million-people.html [Accessed 30 August 2014]

Moss, Timothy (2008) "Cold spots" of Urban Infrastructure: "Shrinking" Processes in Eastern Germany and the Modern Infrastructural Ideal', International Journal of Urban and Regional Research, 32(2), 43651.

Rancière, Jacques (1999) Disagreement: Politics and Philosophy. Minneapolis: University of Minnesota Press

Sassen, Saskia (2010) 'The city: Its return as a lens for social theory', City, Culture and Society 1:1, 3-11 
Skeates, Richard (1997) 'The Infinite City', City, 2:8, pp.6-20 